\title{
PENGARUH GAYA KEPEMIMPINAN DAN MOTIVASI KEPALA SEKOLAH TERHADAP KINERJA GURU DI MADRASAH UNGGULAN HIKMATUL AMANAH
}

\author{
Abdurahman Jemani ${ }^{1}$, Abdul Ghofar Ismail ${ }^{2}$, Abu Darim ${ }^{3}$ \\ ${ }^{123}$ Institut Pesantren KH. Abdul Chalim Mojokerto \\ Email: abdurrahmancendikia@gmail.com
}

\begin{abstract}
ABSTRAK
Kinerja guru merupakan salah satu faktor penting dalam menunjang mutu pendidikan. Penelitian ini membahas gaya kepemimpinan dan motivasi kepala sekolah terhadap kinerja guru di Madrasah Aliyah Unggulan Hikmatul Amanah Bendunganjati Pacet Mojokerto.Jenis penelitian yang digunakan adaah penelitian kuantitatif dengan populasi berjumlah 30 orang dan sampel berjumlah 30 orang yang tergolong sampel jenuh. Penelitian ini merupakan jenis penelitian kuantitif dengan menggunakan pendekatan asisiatif kausal atau sebab akibat. Hasil penelitian menunjukan: (1) Terdapat pengaruh yang signifikan antara gaya kepemimpinan kepala sekolah terhadap kinerja guru, 2) Terdapat pengaruh yang signifikan antara motivasi kepala sekolah terhadap kinerja guru, dan 3) Terdapat pengaruh yang signifikan secara bersama antara gaya kepemimpinan dan motivasi kepala sekolah terhadap kinerja guru di Madrasah Aliyah Unggulan Hikmatul Amanah Bendunganjati Pacet Mojokerto. Hal ini menunjukan bahwa gaya kepemimpinan dan motivasi kepala sekolah yang baik berpengaruh yang signifikan pada peningkatan kinerja guru. Sehingga menjadi perhatian bersama bagi para pimpinan lembaga pendidikan dalam menerapkan gaya kepemimpinan serta pemberian motivasi kepada guru yang berdampak pada semangat kerja dan meningkatnya kinerja guru.
\end{abstract}

Kata Kunci : Gaya Kepemimpinan, Motivasi Kepala Sekolah, Kinerja Guru.

\begin{abstract}
Teacher performance is one of the important factors in supporting the quality of education. This study discusses the leadership style and motivation of school principals on teacher performance in Madrasah Aliyah Unggulan Hikmatul Amanah Bendunganjati Pacet Mojokerto.The type of research used is quantitative research with a population of 30 people and a sample of 30 people belonging to saturated samples. This research is a type of quantitative research using a causal or causal approach. The results showed: (1) There was a significant influence between the principal's leadership style on teacher performance, 2) There was a significant influence between the principal's motivation on the teacher's performance, and 3) There was a significant influence jointly between the leadership style and the principal's motivation on the performance of teachers in Madrasah Aliyah Unggulan Hikmatul Amanah Bendunganjati Pacet Mojokerto. This shows that the leadership style and motivation of good principals have a significant effect on improving teacher performance. So that it becomes a common concern for leaders of educational institutions in implementing leadership styles and providing motivation to teachers that have an impact on morale and improving teacher performance.
\end{abstract}

Keywords: Leadership Style, Principal Motivation and Teacher Performance. 


\section{PENDAHULUAN}

Dalam Undang-Undang Nomor 20 tahun 2003 tentang Sistem Pendidikan Nasional Bab I Pasal 1 ayat (1) dikemukakan bahwa pendidikan adalah usaha sadar dan terencana untuk mewujudkan suasan belajar dan pembelajaran agar peserta didik secara aktif mengembangkan potensi dirinya untuk memiliki kekuatan spiritual keagamaan, pengendalian diri, kepribadian, kecerdasan, akhlak mulia serta keterampilan yang diperlukan dirinya, masyarakat, bangsa dan negara ${ }^{1}$. Dalam studi yang dilakukan oleh PISA, mutu pendidikan Indonesia yang rendah dikonfirmasikan dengan anggaran dan biaya pendidikan yang langsung dibayar oleh masyarakat akan mengalami kenaikan yang signifikan dari tahun ke tahun $^{2}$. Untuk membangun masyarakat terdidik dan cerdas maka diperlukan inovasi baru dalam dunia pendidikan.

Formalitas dan legalitas tetap saja menjadi suatu yang penting, akan tetapi perlu diingat bahwa substansi juga bukan sesuatu yang bisa diabaikan hanya untuk mengejar tataran formal saja, maka yang perlu dilakukan sekarang bukanlah menghapus formalitas yang telah berjalan, melainkan menata kembali sistem pendidikan yang ada dengan paradigma baru yang lebih baik ${ }^{3}$. antara lain memperbaiki komponen-komponen pendidikan antara lain adalah guru dan kepala sekolah, guru sebagai pengajar yang melakukan transfer ilmu pengetahuan, tetapi juga sebagai pendidik yang melakukan transfer nilai-nilai sekaligus sebagai pembimbing yang memberikan pengarahan dan menuntun siswa dalam belajar. ${ }^{4}$ sedangkan kepala sekolah merupakan salah satu komponen pendidikan yang berpengaruh dalam meningkatkan kinerja guru. Kepala sekolah bertanggung jawab atas penyelenggaraan kegiatan pendidikan, administrasi sekolah, pembinaan tenaga kependidikan lainnya, dan pendayagunaan serta pemeliharaan sarana dan prasarana. ${ }^{5}$

Oleh karena itu, kepala sekolah harus memiliki kepribadian atau sifat-sifat dan kemampuan serta keterampilan-keterampilan dalam memimpin sebuah lembaga pendidikan secara profesioanal demi terwujudnya lembaga pendidikan yang berkualitas dan berdaya saing. Guru merupakan tenaga pengajar, pembina dan pendidik yang diharapkan mampu mendidik, membimbing, memberikan ilmu pengetahuan dasar dalam segala aspek bidang keilmuan serta mampu menjadi teladan dan memberikan penanaman karakter yang baik terhadap anak didiknya sehingga dapat menjadi faktor penunjang kinerja. Kinerja diartikan sebagai hasil

\footnotetext{
${ }^{1}$ Arifin. Zainal. Evaluasi pembelajaran. Bandung: PT. Remaja Rosda Karya, 2016

${ }^{2}$ Priansa dan Somad. Manajemen supervisi dan kepemimpinan kepala sekolah. Bandung: Alfabeta, 2014

${ }^{3}$ Aunurrahman. Belajar dan Pembelajaran. Bandung: Alfabeta, 2013

${ }^{4}$ Sardiman. Interaksi \& MotivasiBelajar Mengajar. Jakarta: Rajagarfindo Persada, 2012

${ }^{5}$ Priansa dan Somad.Manajemen supervisi dan kepemimpinan kepala sekolah. Bandung:
} Alfabeta, 2014 
dari usaha seseorang yang telah dicapainya dengan kemampuan yang telah dimilikinya pada kondisi terentu. Dendan demikian, kinerja merupakan hasil keterkaitan antara usaha, kemampuan, dan persepsi tugas yang telah dibebankan 6 . Oleh karena itu, kinerja dapat dipengaruhi oleh beberapa faktor, antara lain: harapan mengenai imbalan, dorongan, kemampuan, kebutuhan dan sifat, persepsi terhadap tugas, imbalan eksternal dan internal dan persepsi terhadap tingkat imbalan dan kepuasan kerja. Dalam pelaksanaanya ada beberapa persoalan yang perlu diperhatikan oleh obyek penelitian dalam upaya peningkatan kinerja guru, yakni :1) Kinerja guru yang ada di Madrasah Aliyah Hikmatul Amanah Bendunganjati Pacet Kabupaten Mojokerto perlu ditingkatkan, 2) Disiplin guru harus ditingkatkan lagi agar proses pembelajaran menjadi lebih optimal, 3) Prestasi kerja dan kinerja guru yang kurang mendapat apresiasi dari sekolah, 4) Peningkatan SDM guru melalui pelatihan dan pengembangan keprofesian, 5) Melalui peningkatan tunjangan agar guru senantiasa semangat dan memiliki tanggung jawab lebih terhadap tugas-tugasnya. Beberapa penelitian terdahulu yang relevan dilakukan oleh Nurbaya dkk pada tahun (2015) dengan Judul Gaya Kepemimpinan Kepala Sekolah dalam Meningkatkan Kinerja Guru pada SD Negeri Lambaro Angan Terdapat pengaruh positif yang sangat signifikan antara gaya kepemimpinan kepala sekolah terhadap kinerja guru yang ditunjukkan oleh persamaan garis regresi sederhana $\hat{Y}=138,57+1,65 X 1,2)$ Peningkatan efektivitas gaya kepemimpinan kepala madrasah akan mengakibatkan meningkatnya kinerja guru. Terdapat terdapat pengaruh positif yang sangat signifikan antara kepuasan kerja terhadap kinerja guru yang ditunjukkan oleh persamaan garis regresi sederhana $\hat{Y}=73,05+$. Jumlah Variabel penelitian yang digunakan adalah satu variabel $\mathrm{X}$ dan satu variabel $\mathrm{Y}$. dan yang membebdakan penelitian tersebut dengan penenlitiaan ini adalah pada penelitian ini peneliti menambahkan variabel dua variabek $\mathrm{X}$ dan satu variabel $\mathrm{Y}$. Penelitian terdahulu yang relevan juga pernah dilakukan oleh Ngiode Syafrin (2016) berjudul Pengaruh kepemimpinan kepala sekolah, motivasi kerja dan disiplin kerja terhadap kinerja guru MTs Negeri Batudaa Kabupaten Gorontalo, yang menjadi perbedaan adalah Teknik analisis data yaitu penelitian ini menggunakan analisis deskriptif dan uji persyaratan, 2) Teknik pengambilan sampel menggunakan teknik sensus. 3) Variabel penelitian $X \_1, \quad X \_2$ dan X_3 terhadap Y_1 Berdasarkan paparan di atas, peneliti tertarik untuk mengadakan penelitian dengan Judul Pengaruh Gaya Kepemimpinan dan Motivasi Kepala Sekolah terhadap Kinerja Guru di Madrasah Aliyah Unggulan Hikmatul Amanah

${ }^{6}$ Timpe (1999) dalam Priansa dan Somad .Manajemen supervisi dan kepemimpinan kepala sekolah. Bandung: Alfabeta, 2014 
Bendunganjati Pacet Kabupaten Mojokerto, yang terdiri dari dua variabel X dan satu variabel Y dengan menggunakan pendekatan asosiatif deskriptif.

\section{PEMBAHASAN}

\section{Gaya Kepemimpinan}

Secara leksikal, kata gaya dapat diartikan sebagai sikap, gerakan, irama dan lagu; ragam; cara dalam melakukan gerakan dalam olahraga; lagak lagu tingkah laku; sikap elok; gerak-gerik yang bagus ${ }^{7}$. Pendapat lain menerangkan bahwa gaya kepemimpinan merupakan suatu pola perilaku yang konsisten yang ditujukan oleh seorang pemimpin yang kemudian diketahui oleh pihak lain ketika pemimpin tersebut berusaha mempengaruhi kegiatan-kegitaan orang lain ${ }^{8}$. Djafri mengemukakan gaya kepemimpinan kepala sekolah adalah perilaku kepala sekolah dalam memimpin, mengarahkan, membina dan mempengaruhi bawahan dalam kegiatan pembelajaran di sekolah. Berdasarkan hal tersebut maka dimensi gaya kepemimpinan kepala sekolah dalam penelitian ini adalah bersifat terbuka, mendominasi pelaksanaan tugas, dan situasional ${ }^{9}$.

Gaya kepemimpinan yang efektif ada empat, yaitu sebagai berikut: 1) Gaya instruktif, penerapannya lebih menekankan pada bawahan yang baru bertugas. Ciri-ciri gaya kepemimpinan instruktif ini adalah : a) memberikan arahan secara spesifik tentang apa, bagaimana dan kapan kegiatan tersebut dilakukan, b) kegiatan lebih banyak diawasi secara ketat, c) kadar direktif tinggi, d) kadar semangat rendah, e) kurang dapat meningkatkan kemampuan pegawai, f) kemampuan motivasi rendah, g) tingkat kematangan bawahan rendah., 2) Gaya Konsultatif, Penerapannya pada bawahan yang berkemampuan tinggi namun kemamauan rendah. Ciri - ciri gaya konsultatif adalah sebagai berikut : a) kadar direktif rendah, b) semangat tinggi, c) komunikasi dilakukan secara timbal balik, d) masih memberikan pengarahan spesifik, e) pimpinan secara bertahap memberikan tanggung jawab kepada pegawai walaupun bawahan masih dianggap belum mampu, f) tingkat kematangan bawahan dari rendah ke sedang, 3) Kepemimpinan partisipatif, Kepemimpinan ini juga dikenal sebagai kepemimpinan terbuka, bebas dan nondirective. Pemimpin bertugas mengarahkan tim kepada arah tercapainya konsensus. Asumsi yang menjadi dasar pada gaya kepemimpinan ini adalah bahwa para karyawan akan lebih siap menerima tanggung jawab terhadap solusi, tujuan, dan strategi dimana mereka diberdayakan

\footnotetext{
${ }^{7}$ Baharudin dan Umairso. Kepemimpinan Pendidikan Islam . (Jogjakarta, , Ar Ruzz Media,) 2012

8 Priansa dan Somad .Manajemen Supervisi dan Kepemimpinan Kepala Sekolah. Bandung: Alfabeta, 2014

9 Novianty Djafri, "PENGARUH GAYA KEPEMIMPINAN, EMPATI DAN MOTIVASI TERHADAP BUDAYA ORGANISASI (Studi Kasus Terhadap Kepala Sekolah Dasar Kota Gorontalo)," Jurnal Manajemen 19, no. 1 (2015): 63, https://doi.org/10.24912/jm.v19i1.105.
} 
untuk mengembangkannya, 4) Gaya delegasi, penerapannya bagi bawahan yang memiliki kemampuan dan kemauan tinggi. Ciri-ciri gaya kepemimpinan ini adalah sebagai berikut : a) memberikan pengarahan bila diperlukan saja, b) memberikan semangat dianggap tidak perlu lagi, c) penyerahan tanggung jawab kepada pihak bawahan untuk mengatasi dan menyelesaikan tugas, d) tidak perlu memberikan motivasi, e) tingkat kematangan bawahan tinggi ${ }^{10}$.

\section{Pengertian Pemimpin dan Kepemimpinan}

Pemimpin berasal dari kata "leader" dan kepemimpinan berasal dari kata "leadership" Pemimpin adalah pionir dan merupakan pribadi terpilih pada suatu instansi atau lembaga yang paling berorientasi pada visi,misi hasil, dimana hasil tersebut akan diperoleh jika pemimpin tersebut mengetahui dan memahami apa yang diinginkannya ${ }^{11}$. Menurut Mulyasa, Kepemimpinan dapat diartikan sebagai kegiatan untuk mempengaruhi sekelompok orang yang diarahakan menuju tujuan organisasi $^{12}$, Lebih lanjutkan dikemukakan oleh Basri, Kepemimpinan dapat diartikan sebagai manifestasi dari pengaruh yang melekat pada jiwanya ${ }^{13}$. Pendapat lain diekemukakan oleh Sule dan Saefullah bahwa kepemimpinan dapat diartikan sebagai proses mempengaruhi dan mengarahkan para pegawai dalam melakukan pekerjaan yang telah ditugaskan kepada mereka ${ }^{14}$. Dari beberapa definisi kepemimpinan diatas, penulis menyimpulkan bahwa kepemimpinan merupakan kemampuan personal yang dimilki seseorang dalam mempengaruhi orang lain untuk bersedia diarahkan dan diatur demi mencapai visi, misi dan tujuan tertentu. tugas profesional kepala sekolah adalah sebagai educator, manager, administrator, supervisor, inovator, dan motivator atau diakronimkan dengan EMASLIM, yang kemudian diuraikan sbagai berikut :

1) Educator (Edukator), Kepala sekolah berperan sebagai pendidik dapat dilihat pada kemampuanya sebagai guru. Sebagai guru keapala sekolah harus mampu menyusun program pembelajaran, melaksanakan kegiatan belajar mengajar, melaksanakan evaluasi, melakukan analisis hasil belajar dan kemudian melakukan pengayaan atau perbaikan.

2) Manager (Manajer), Sebagai manajer, kepala sekolah harus mampu menyusun program kerja di sekolah, menyusun organisasi kepegawaian yang tepat sesuai bidang keilmuan dan keahlian, mampu menggerakkan staf

${ }^{10}$ Baharudin dan Umairso. Kepemimpinan Pendidikan Islam . (Jogjakarta, , Ar Ruzz Media), 2012

11 Priansa dan Somad . Manajemen Supervisi dan Kepemimpinan Kepala Sekolah. Bandung: Alfabeta, 2014 Hlm. 107

${ }_{12}$ E. Mulyasa. Manajemen Berbasis Sekolah. (Bandung:PT. Remaja Rosdakarya,2014).

${ }^{13}$ Hasan Basri. Kepemimpinan Kepala Sekolah. Bandung: CV. Pustaka Setia, 2014

${ }^{14}$ Sule.E.T dan K. Saefullah. Pengantar Manajemen. Bandung: Prenadamedia Group, 2018 
untuklebih giat dalam melaksanakan tugas, dan mampu mengoptimalkan semua sumber daya yang dimilki oleh sekolah

3) Administrator (Pelaku Administrasi), kepala sekolah mampu mengelolah administrasi proses belajar mengajar dan bimbingan konseling, mampu mengelolah administasi kesiswaan, mampu mengelolah administrasi keuangan, yang diwujudkan dalam kelengkapan dan akuntabilitas tentang penggunaan dan laporan keuangan, serta mampu menginventarisir saran prsarana dan mampu mengelolah administrasi persuratan.

4) Supervisor (Pengawas), kepala sekolah memiliki kemampuan sebagai supervisi pendidikan yang kemudian hasil supervisi tersebut diperbaiki demi peningkatan kualitas pendidikan di sekolah.

5) Inovator (Pemberi Inovasi), Kepala sekolah harus memiliki inovasi tinggi serta mampu mencari dan menemukan gagasan - gagasan untuk pembaharuan sekolah dan melaksanakn pembaharuan di sekolah.

6) Motivator (Pemberi Motivasi), kepala sekolah mampu memberi motivasi kepada semua warga sekolah. Kemampuan sebagai motivator dapat dilihat dari cara kepala sekolah mengatur lingkungan kerja dan suasan kerja yang nyaman sehingga mmunculkan kreatifitas dan ide-ide cemerlang dari warga sekolah, selain itu, kepala sekolah harus mampu memberikan penghargaan bagi warga sekolah yang berprestasi serta memberikan sanksi terhadap warga sekolah yang melanggar peraturan sekolah yang telah disepakati bersama $^{15}$.

\section{Motivasi Kepala Sekolah}

Motivasi berasal dari kata latin movere yang berarti dorongan atau menggerakkan ${ }^{16}$. Lebih lanjut dikemukakan oleh Hikmat, Motivasi berasal dari kata "motif" dalam bahasa inggris adalah "motive" atau "motion" lalu "motivation" yang berarti gerakan atau sesuatu yang bergerak. Artinya sesuatu yang menggerakkan terjadinya tindakan atau disebut dengan niat. Pada dasarnya perbuatan manusia dapat dibagi menjadi tiga macam, yakni, perbuatan yang direncanakan, artinya digerakkan oleh suatu tujuan yang akan dicapai; perbuatan yang tidak direncanakan, yang bersifat spontanitas, artinya tidak bermotif; dan perbuatan yang berada diantara dua keadaan, yaitu direncanakan dan tidak direncanakan, yang disebut dengan semi direncanakan. Motivasi atau dorongan sangat kuat dalam menentukan terwujudnya suatu perbuatan yang direncanakan, selanjutnya, motivasi dilakukan dengan tujuan berikut :1) Merangsang seseorang untuk bekerja dengan baik, 2) Mendorong seseorang untuk bekerja lebih

15 Priansa dan Somad. Manajemen Supervisi dan Kepemimpinan Kepala Sekolah. Bandung: Alfabeta, 2014

${ }^{16}$ Hasibuan. Manajemen Sumber Daya Manusia . Jakarta; PT Bumi Aksara 2016 
berprestasi, 3) Mendorong seseorang untuk bekerja dengan penuh tanggung jawab, 4) Meningkatkan kualitas kerja, 5) Mengembangkan produktifitas kerja, 6) Menaati peraturan yang berlaku, 7) Jera dalam melanggar aturan, 8) Mengarahkan perilaku untuk mencapai tujuan, 9) Mempertahankan prestasi kerja dan bersaing secara positif. Tujuan-tujuan motivasi yang dijabarkan diatas merupakan bagian dari pengertian motivasi yang sesungguhnya. Dalam organisasi pendidikan, motivasi kerja sangat dibutuhkan demi kelancaran penyelenggaran proses pembelajaran dan berjalannya roda pendidikan. Motivasi untuk para guru dan dosen dapat dilakukan dengan cara memberikan bantuan beasiswa kuliah, meningkatkan insentif dan honor dari pekerjaannya, dan berbagai cara lain yang dapat digunakan dalam rangka meningkatkan motivasi kerja ${ }^{17}$. Menurut Frederich Herzberg ada dua jenis faktor yang mendorong seseorang untuk berusaha mencapai kepuasan dan menjauhkan diri dari ketidakpuasan. Dua faktor itu disebutnya faktor higiene (faktor ekstrinsik) dan faktor motivator (faktor intrinsik). Berdasarkan uraian tersebut Herzberg menyimpulakan ada dua dimensi dalam motivasi yaitu: Pertama. Dimensi dari dalam atau faktor intrinsik yaitu daya dorong yang timbul dari dalam diri masing-masing orang, factor meliputi (1) Pencapaian prestasi, (2) Pengakuan, (3) Tanggung Jawab, (4) Kemajuan, (5) Pekerjaan itu sendiri, (6) Kemungkinan berkembang. Kedua. Dimensi dari luar atau dimensi ektrinsik yaitu daya dorong yang datang dari luar diri seseorang, terutama dari organisasi tempatnya bekerja. Faktor - faktor ekstrinsik ( konteks pekerjaan ) meliputi : (1) Upah, (2) Kondisi kerja, (3) Keamanan kerja, (4) Status, (5) Prosedur perusahaan, (6) Mutu penyeliaan, (7) Mutu hubungan interpersonal antar sesama rekan kerja, atasan, dan bawahan. ${ }^{18}$

\section{Kinerja Guru}

Nayyar (Khan, Shah, Khan, et al., 2012: 23) menyatakan kinerja merupakan kemampuan seseorang dalam melakukan pekerjaan tertentu, dinilai berdasarkan standar yang telah ditetapkan ${ }^{19}$. Kinerja guru dapat dipersepsikan sebagai perilaku kerja yang ditunjukkan guru dalam melaksanakan tugastugasnya. Tugas tersebut dibebankan kepadanya yang didasarkan atas kecakapan, pengalaman, dan kesungguhan serta waktu kerja. Guru yang yang memiliki kinerja yang tinggi tentu akan menghasilkan yang terbaik sesuai tujuan. Sebagai bagian dari institusi pendidikan, guru diharapkan dapat menyukseskan tujuan pendidikan nasional melalui peningkatan kualitas pembelajaran. Dengan

${ }^{17}$ Hikmat. Manajemen Pendidikan.. Bandung: CV. Pustaka Setia, 2014

18 Nachrowi Iman Santoso, "PENGARUH KEPEMIMPINAN KEPALA SEKOLAH DAN MOTIVASI KERJA TERHADAP KINERJA GURU SMK BUDI MULIA TANGERANG," MIX: JURNAL ILMIAH MANAJEMEN 3, no. 3 (May 6, 2015): 275, https://publikasi.mercubuana.ac.id/index.php/Jurnal_Mix/article/view/92.

${ }^{19}$ Khan, A., Shah, I. M., Khan, S., et al. (2012). Teacher Stress, Performance \& Resources The Moderating Effect of Resour-ces on Stress and Performnace. Inter-national Review of Social Science and Humanities, Vol.2, No. 2, 21-29. 
pembelajaran yang berkualitas, prestasi peserta didik akan meningkat ${ }^{20}$. Sahertian menyatakan,batasan tentang kriteria kinerja guruyang baik,yaitu bagiseorang guruharus mampu rnelayani pembelajaran siswa secara individu dan kelornpok, membuat perencanaan pembelajaran,menggunakan media pembelajaran dan melibatkan siswa dalam berbagai pengalaman belajar,dan dapat menempatkan diri sebagai pemimpin dan fasilitator yang aktif bagi para siswanya ${ }^{21}$.

Selanjutnya, pada buku yang lain, Sahertian mengemukakan bahwa guru yang profesional memiliki ciri-ciri (1) memiliki kemampuan dan ahli dalam pendidikan dan pembelajaran; (2) bertanggung jawab, yakni memiliki komitmen terhadap tugasnya; (3) memiliki rasa kebersamaan dan menghayati tugasnya sebagai bentuk karier hidup serta dapat menjunjung tinggi kode etik guru. Tugas pokok dan fungsi guru yang diwujudkan dalam aktivitas pembelajaran merupakan bentuk kinerja guru. Dalam merencanakan pembelajaran harus dibuat sebaik mungkin, ini karena perencanaan yang baik akan menghasilkan pembelajaran yang efektif dan efisien ${ }^{22}$.

Dalam upaya meningkatan kinerja guru tidak terlepas dari faktor pendukung dan penghambat, Faktor pendukung dalam meningkatkan kinerja guru, antara lain (1) memberikan reward pada guru yang berprestasi melalui penilaian rapot guru yang diberikan setiap awal semester untuk diisi sendiri dan di akhir semester akan di setorkan ke kepala sekolah melalui koordinator jenjang. Reward diberikan oleh yayasan kepada seluruh guru yang berprestasi, reward berupa sepeda motor (hak pakai selama 3 tahun), undian umroh ke tanah suci mekah; (2) hubungan yang sinergis antara kepala sekolah dengan guru, guru dengan guru serta kerjasama guru untuk memudahkan dalam meningkatkan semangat kinerja; (3) pihak masyarakat yang mendukung proses pendidikan serta kegiatan sekolah. Sementara itu, faktor penghambat dalam meningkatkan kinerja guru, antara lain (1) perbedaan karakter guru berdampak pada kinerja guru; (2) guru yang tidak linier, menyebabkan kurang maksimal dalam memberikan materi kepada siswa; (3) adanya senioritas dalam situasi kerja, menyebabkan tidak seimbangnya pembagian kinerja atau tugas pokok; (4) banyaknya tugas yang harus dikerjakan guru, apabila pekerjaan yang tidak selesai di sekolah lalu diselesaikan di rumah. Adapun usaha dalam menyelesaikan hambatan untuk meningkatkan kinerja guru, yakni (a) kepala sekolah menggunakan pendekatan persuasif, untuk lebih memahami karakter dari individu guru, setelah itu kepala sekolah memberikan

${ }^{20}$ Aan Ansori, Ahmad Supriyanto, and Burhanuddin Burhanuddin, "PELAKSANAAN SUPERVISI KLINIS DALAM MENINGKATKAN KINERJA GURU SEKOLAH DASAR," Jurnal Pendidikan: Teori, Penelitian, dan Pengembangan 1, no. 12 (December 1, 2016): 2323, https://doi.org/10.17977/jp.v1i12.8285.

${ }^{21}$ Sahertian, P.A \& Saherian, I. A. 1995. Supervisi Pendidikan Dalam Rangka Program Inservise Education. Jakarta: Rineka Cipta.

${ }_{22}$ Sahertian, P.A. 2008. Konsep Dasar \& Teknik Supervisi Pendidikan: Dalam Pengembangan Sumber Daya Manusia. Jakarta: Rineka Cipta 
arahan dan masukan kepada guru yang bersangkutan; (b) membuat tingkatan level kinerja guru, seperti (1) level profesional (fast-trek); (2) level sedang; (3) level tidak profesional.

Dari ketiga level ini kepala sekolah bisa membagi tingkatan kinerja guru yang bisa diketahui melalui penyerahan rapor guru di akhir semester kepada koordinator jenjang kepada kepala sekolah; (c) mengadakan supervisi kelas terstruktur, dilakukan oleh koordinator jenjang yang sudah dijadwalkan dalam program sekolah yang pelaksaannya dua kali dalam satu tahun (dua kali dalam dua semester) dan supervisi kelas tidak terstruktur, yang dilakukan oleh kepala sekolah secara spontanitas diluar program sekolah; (d) memberikan kesempatan kepada guru untuk kuliah lagi dengan mengambil jurusan yang linier; (e) mengikutkan pelatihan pada guru baik pelatihan internal maupun eksternal sekolah $^{23}$. Menurut Usman dalam bukunya yang berjudul Metodologi Penelitian Sosial, menjelaskan bahwa kinerja selalu merupakan tanda keberhasilan suatu organisasi dan orang-orang yang ada dalam organisasi tersebut. Diperjelas oleh Hamzah, Bila yang dimaksud adalah kinerja guru dalam mengajar, maka kinerja itu tampak pada hasil kerja guru yang terefleksi dalam cara merencanakan, melaksanakan, dan menilai proses belajar mengajar (PBM) yang intensitasnya dilandasi etos kerja, serta disiplin professional guru dalam proses pembelajaran ${ }^{24}$

\section{Syarat-Syarat Penilaian Kinerja Guru}

Menurut Daryanto, persyaratan-persyratan yang harus dipenuhi untuk memperoleh penilaian kinerja guru yang benar dan tepat adalah sebagai berikut.

1) Valid, Sistem penilaian kinerja guru dikatan valid bila aspek yang dinilai benar-benar mengukur komponen-komponen guru dalam melaksanakan pembelajaran, pembimbingan dan/ atau lain yang relevan dengan fungsi sekolah/ madrasah.

2) Reliabel, Sistem penilaian kinerja guru dapat dikatan reliabel atau mempunyai tingkat kepercayaan tinggi bila proses yang dilakukan memberikan hasil yang sama untuk seorang guru yang dinilai yang akan dinilai kinerjanya oleh siapapun dan kapanpun

3) Praktis, Sistem penilaian kinerja guru dikatakan praktis biladapat dilakukan oleh siapapun dengan mudah, dengan tingkat validitas dan

\footnotetext{
${ }^{23}$ Wahyu Ramadoni, Kusmintardjo Kusmintardjo, and Imron Arifin, "KEPEMIMPINAN KEPALA SEKOLAH DALAM UPAYA PENINGKATAN KINERJA GURU (STUDI MULTI KASUS DI PAUD ISLAM SABILILLAH DAN SDN TANJUNGSARI 1 KABUPATEN SIDOARJO)," Jurnal Pendidikan: Teori, Penelitian, dan Pengembangan 1, no. 8 (August 1, 2016): 1502, https://doi.org/10.17977/jp.v1i8.6620.

${ }^{24}$ Hamzah B. U. (2013). Teori Motivasi\& Pengukurannya. Jakarta: PT Bumi Aksara.
} 
reliabilitas yang sama dalam semua kondisi tanpa memerlukan persyaratan tambahan ${ }^{25}$.

\section{Prinsip Pelaksanaan Penilaian Kinerja Guru}

Daryanto menjelaskan bahwa Agar hasil penilaian kinerja guru dapat dipertanggungjawabkan, maka harus memenuhi prinsip-prinsip sebagai berikut: 1) Berdasarkan ketentuan, yakni penilaian kinerja guru harus dilaksanakan sesuai dengan prosedur dan mengacu pada peraturan yang berlaku, 2) Berdasarkan kinerja, yakni aspek yang dinilai dalam penilaian kinerja guru adalah kinerja guru tersebut, yang meliputi : kegiatan pembelajaran, pembimbingan dan tpelaksaaan tugas-tugas tambahan yang relevan dengan fungsi sekolah/ madrasah, 3) Berlandaskan dokumen, yakni penilai, guru yang dinilai dan unsur lan yang terlibat dalam proses penilain kinerja guru harus memahami semua dokumen yang berkaitan dengan sistem penilain kinerja guru, 4) Dilaksanakan secara kinsisten, yakni dilaksanakan secara teratur setiap tahun pelajaran dengan diawali dengan evaluasi diri dan bersifat objektif, adil, akuntabel, bermanfaat, transparansi, berorientasi pada tujuan, berorientasi pada proses, berkelanjutan dan bersifat rahasia $^{26}$

\section{METODOLOGI}

Penelitian ini merupakan penelitian kuantitatif yang merupakan jenis penelitian yang spesifikasinya secara sistematis, terencana dan terstruktur sejak awal rumusan masalah hingga desain penelitian. ${ }^{27}$. Teknik pengumpulan data pada penelitian ini yaitu dengan menggunakan cross section dengan menggunakan median kuisioner atau angket ${ }^{28}$. Dalam penelitian ini kuesioner yang digunakan peneliti adalah kuesioner langsung tertutup yaitu angket yang dibuat berisikan tentang keadaan yang dialami responden. Peneliti juga memberikan alternatif jawaban yang nantinya responden memilih jawaban yang sesuai dengan keadaan yang terjadi. Kuesioner yang disediakan oleh peneliti ini digunakan untuk mendapatkan data mengenai gaya kepemimpinan, motivasi kepala sekolah dan kinerja guru yang diukur dengan menggunakan Skala Likert. Populasi pada penelitian ini adalah bapak dan ibu guru yang ada di Madrasah Aliyah Unggulan Hikmatul Amanah Bendunganjati Pacet Kabupaten Mojokerto sebanyak 30 orang. Teknik pengambilan sampel yang dipakai dalam penelitian ini adalah sampling jenuh yakni semua anggota populasi dijadikan sebagai sampel penelitian. Pada sampel jenuh ini, sering kali diartikan sebgai sampel yang sudah

${ }^{25}$ Daryanto. Standar Kompetensi dan Penilaian Kinerja Guru Profesional. Yogyakarta: Penerbit Gava Media, 2013

${ }^{26} \mathrm{Ibid}$.

${ }^{27}$ Sugiyono, Metode Penelitian Kuantitatif, Kualitatif Dan R\&D, Bandung: Alfabeta, 2016

${ }^{28}$ Ardial, Paradigma dan Model Penelitian Komunikasi, Jakarta: Bumi Aksara, 2014 
maksimum, ditambah berapapun tidak akan merubah keterwakilan ${ }^{29}$. Adapun jumlah sampel dalam penelitian ini berjumlah 30 responden. Data diolah menggunakan bantuan aplikasi SPSS Versi 25.0 for Windows. Jumlah responden pada penelitian ini berjumlah 30 orang yang terdiri dari bapak dan ibu guru yang ada di Madrasah Aliyah Unggulan Hikmatul Amanah Bendunganjati Pacet Kabupaten Mojokerto.

HASIL DAN PEMBAHASAN

Hasil Penelitian

Tabel Uji Validitas Instrumen Gaya Kepemimpinan (X1)

\begin{tabular}{|l|l|l|l|}
\hline No. Butir & r hitung & r tabel & Keterangan \\
\hline $\mathbf{1}$ & 0,565 & 0,361 & Valid \\
\hline $\mathbf{2}$ & 0,579 & 0,361 & Valid \\
\hline $\mathbf{3}$ & 0,426 & 0,361 & Valid \\
\hline $\mathbf{4}$ & 0,359 & 0,361 & Valid \\
\hline $\mathbf{5}$ & 0,478 & 0,361 & Valid \\
\hline $\mathbf{6}$ & 0,725 & 0,361 & Valid \\
\hline $\mathbf{7}$ & 0,426 & 0,361 & Valid \\
\hline $\mathbf{8}$ & 0,639 & 0,361 & Valid \\
\hline $\mathbf{9}$ & 0,515 & 0,361 & Valid \\
\hline $\mathbf{1 0}$ & 0,566 & 0,361 & Valid \\
\hline $\mathbf{1 1}$ & 0,625 & 0,361 & Valid \\
\hline $\mathbf{1 2}$ & $-0,295$ & 0,361 & Tidak Valid \\
\hline $\mathbf{1 3}$ & 0,801 & 0,361 & Valid \\
\hline $\mathbf{1 4}$ & $-0,324$ & 0,361 & Tidak Valid \\
\hline $\mathbf{1 5}$ & 0,678 & 0,361 & Valid \\
\hline $\mathbf{1 6}$ & 0,518 & 0,361 & Valid \\
\hline $\mathbf{1 7}$ & 0,496 & 0,361 & Valid \\
\hline $\mathbf{1 8}$ & 0,444 & 0,361 & Valid \\
\hline $\mathbf{1 9}$ & $-0,020$ & 0,361 & Tidak Valid \\
\hline $\mathbf{2 0}$ & 0,724 & 0,361 & Valid \\
\hline $\mathbf{2 1}$ & 0,378 & 0,361 & Valid \\
\hline $\mathbf{2 2}$ & 0,565 & 0,361 & Valid \\
\hline $\mathbf{2 3}$ & 0,447 & 0,361 & Valid \\
\hline $\mathbf{2 4}$ & 0,620 & 0,361 & Valid \\
\hline
\end{tabular}

\footnotetext{
${ }^{29}$ Sugiyono, M etode Penelitian Kuantitatif, Kualitatif dan R\&D, Bandung: Alfabeta, 2016
} 
Tabel Validitas Instrumen Motivasi Kepala Sekolah (X2)

\begin{tabular}{|l|l|l|l|}
\hline No. Butir & r hitung & r tabel & Keterangan \\
\hline $\mathbf{1}$ & 0,714 & 0,361 & Valid \\
\hline $\mathbf{2}$ & 0,481 & 0,361 & Valid \\
\hline $\mathbf{3}$ & 0,808 & 0,361 & Valid \\
\hline $\mathbf{4}$ & 0,588 & 0,361 & Valid \\
\hline $\mathbf{5}$ & $-0,035$ & 0,361 & Tidak Valid \\
\hline $\mathbf{6}$ & $-0,030$ & 0,361 & Tidak Valid \\
\hline $\mathbf{7}$ & 0,687 & 0,361 & Valid \\
\hline $\mathbf{8}$ & 0,458 & 0,361 & Valid \\
\hline $\mathbf{9}$ & 0,045 & 0,361 & Tidak Valid \\
\hline $\mathbf{1 0}$ & 0,625 & 0,361 & Valid \\
\hline $\mathbf{1 1}$ & 0,668 & 0,361 & Valid \\
\hline $\mathbf{1 2}$ & 0,519 & 0,361 & Valid \\
\hline $\mathbf{1 3}$ & 0,368 & 0,361 & Valid \\
\hline $\mathbf{1 4}$ & 0,633 & 0,361 & Valid \\
\hline $\mathbf{1 5}$ & 0,693 & 0,361 & Valid \\
\hline $\mathbf{1 6}$ & 0,595 & 0,361 & Valid \\
\hline $\mathbf{1 7}$ & 0,522 & 0,361 & Valid \\
\hline $\mathbf{1 8}$ & 0,438 & 0,361 & Valid \\
\hline $\mathbf{1 9}$ & 0,501 & 0,361 & Valid \\
\hline $\mathbf{2 0}$ & 0,828 & 0,361 & Valid \\
\hline
\end{tabular}

Tabel. Uji Validitas Kinerja Guru (Y)

\begin{tabular}{|l|l|l|l|}
\hline No. Butir & r hitung & r tabel & Keterangan \\
\hline $\mathbf{1}$ & 0,528 & 0,361 & Valid \\
\hline $\mathbf{2}$ & 0,507 & 0,361 & Valid \\
\hline $\mathbf{3}$ & 0,758 & 0,361 & Valid \\
\hline $\mathbf{4}$ & 0,485 & 0,361 & Valid \\
\hline $\mathbf{5}$ & 0,496 & 0,361 & Valid \\
\hline $\mathbf{6}$ & 0,495 & 0,361 & Valid \\
\hline $\mathbf{7}$ & 0,631 & 0,361 & Valid \\
\hline $\mathbf{8}$ & 0,713 & 0,361 & Valid \\
\hline $\mathbf{9}$ & 0,461 & 0,361 & Valid \\
\hline $\mathbf{1 0}$ & 0,638 & 0,361 & Valid \\
\hline $\mathbf{1 1}$ & 0,418 & 0,361 & Valid \\
\hline $\mathbf{1 2}$ & 0,770 & 0,361 & Valid \\
\hline $\mathbf{1 3}$ & 0,483 & 0,361 & Valid \\
\hline $\mathbf{1 4}$ & 0,701 & 0,361 & Valid \\
\hline
\end{tabular}


Suatu kuesioner dinyatakan reliabel apabila nilai $\mathrm{r}$ hitung lebih besar daripada nilai $r$ tabel dengan gtaraf signifikansi $5 \%$.

Tabel Rangkuman Reliabilitas Instrumen

\begin{tabular}{|l|l|l|l|}
\hline No & Variabel & Cronbach'c Alpha & Ket. \\
\hline 1 & Gaya Kepemimpinan & 0,889 & Reliabel \\
\hline 2 & Motivasi Kepala Sekolah & 0,855 & Reliabel \\
\hline 3 & Kinerja Guru & 0,851 & Reliabel \\
\hline
\end{tabular}

\section{Deskripsi Variabel Penelitian}

Penelitian akan mendeskripsikan setiap variabel penelitian dengan ditunjang oleh data yang diperoleh dari penyebaran kuesioner penelitian dan kemudian dinalisis secara sistematis.. Adapun uraian dari setiap hasil penelitian berdasarkan deskripsi statistik akan di paparkan pada tabel di bawah ini.

\section{Tabel Deskripsi Statistik}

\begin{tabular}{|l|l|l|l|l|l|l|}
\hline No & Variabel & N & Minimum & Maximum & Mean & Std. Deviation \\
\hline 1 & $\begin{array}{l}\text { Gaya } \\
\text { Kepemimpinan }\end{array}$ & 30 & 60 & 94 & 79,63 & 8,60 \\
\hline 2 & $\begin{array}{l}\text { Motivaasi } \\
\text { Kepala Sekolah }\end{array}$ & 30 & 56 & 85 & 70,1 & 6,45 \\
\hline 3 & Kinerja Guru & 30 & 50 & 70 & 60,87 & 6,47 \\
\hline
\end{tabular}

Hasil penelitian pada masing-masing variabel, akan dipaparkan lebih rinci pada pembahasan dibawah ini.

1. Gaya Kepemimpinan

Peneliti akan memaparkan dan membahas data hasil penelitian yang meliputi skor total yang dikhusukan pada variabel gaya kepemimpinan di Madrasah Unggulan Hikmatul Amanah Bendunganjati Pacet Kabupaten Mojokerto sebagaimana yang dijabarkan pada tabel di bawah ini.

Tabel Skor Total Gaya Kepemimpinan

\begin{tabular}{|l|l|l|l|}
\hline No & Variabel & Jumlah Item & Skor Total \\
\hline 1 & Gaya Kepemimpinan & 24 & 2389 \\
\hline
\end{tabular}

Hasil penelitian juga akan dipaparkan dengan menggunakan analisis deskripsi statistik menggunakan bantuan Aplikasi SPSS 25.0 for windows seperti yang digambarkan pada pada gambar dibawah ini. 
Gambar Deskripsi Statistik Gaya Kepemimpinan

\begin{tabular}{|c|c|c|}
\hline \multicolumn{3}{|c|}{ Statis tics } \\
\hline \multicolumn{3}{|c|}{ Gaya Kepemimpinan } \\
\hline \multirow[t]{2}{*}{$\mathbf{N}$} & Valid & 30 \\
\hline & Missing & $\mathrm{O}$ \\
\hline \multicolumn{2}{|l|}{ Mean } & 79,63 \\
\hline \multicolumn{2}{|l|}{ Median } & 79,50 \\
\hline \multicolumn{2}{|l|}{ Mode } & 85 \\
\hline \multicolumn{2}{|c|}{ Std. Deviation } & 8,600 \\
\hline \multicolumn{2}{|c|}{ Variance } & 73,964 \\
\hline \multicolumn{2}{|l|}{ Range } & 34 \\
\hline \multicolumn{2}{|c|}{ Minimum } & 60 \\
\hline \multicolumn{2}{|c|}{ Maximum } & 94 \\
\hline \multicolumn{2}{|l|}{ Sum } & 2389 \\
\hline
\end{tabular}

Berdasarkan gambar di atas, dapat dilihat bahwa jumlah responden yang dijadikan sampel berjumlah 30 orang dengan skor total kuesioner gaya kepemimpinan sebesar 2389 dari 24 item pernyataan yang dijabarkan pada kuesioner gaya kepemimpinan. Mean atau nilai rata-rata 79,63 dengan standar deviasi sebesar 8,60 dan Skor jawaban tertinggi sebesar 94 dan terendah sebesar 60. Berdasarkan analisa jumlah data maximum dan minimum tersebut maka peneliti dapat membuat kategori atau klasifikasi skor pada gaya kepemimpinan.

Adapun tabel pengkategorian gaya kepemimpinan akan sebagai berikut.

Tabel Kategori Gaya Kepemimpinan Kepala Sekolah

\begin{tabular}{|l|l|l|}
\hline No & Skor & Kategori \\
\hline 1 & $78-84$ & Sangat Baik \\
\hline 2 & $72-78$ & Baik \\
\hline 3 & $66-72$ & Cukup \\
\hline 4 & $60-66$ & Kurang Baik \\
\hline
\end{tabular}

Berdasarkan tabel tentang kategori gaya kepemimpinan di atas, dapat dilihat bahwa gaya kepemimpinan kepala sekolah pada Madrasah Aliyah Unggulan Himatul Amanah Bendunganjati Pacet Kabupaten Mojokerto berada pada rata-rata 79,63 dengan kategori Sangat baik.

1. Motivasi Kepala Sekolah

Peneliti akan memaparkan dan membahas data hasil penelitian yang meliputi skor total yang dikhusukan pada variabel motivasi kepala sekolah di Madrasah Unggulan Hikmatul Amanah Bendunganjati Pacet Kabupaten Mojokerto sebagaimana yang dijabarkan pada tabel 4.4 dibawah ini. 
Tabel 4.14 Skor total motivasi kepala sekolah

\begin{tabular}{|l|lr|l|l|}
\hline No & Variabel & Jumlah Item & Skor Total \\
\hline 1 & $\begin{array}{l}\text { Motivasi } \\
\text { Sekolah }\end{array}$ & Kepala & 20 & 2103 \\
\hline
\end{tabular}

Hasil penelitian juga akan dipaparkan dengan menggunakan analisis deskripsi statistik menggunakan bantuan Aplikasi SPSS 25.0 for windows seperti yang digambarkan pada pada gambar dibawah ini.

Gambar Deskripsi Statistik Motivasi Kepala Sekolah

\begin{tabular}{|c|c|c|}
\hline \multicolumn{3}{|c|}{ Statis tics } \\
\hline & & kolah \\
\hline \multirow[t]{2}{*}{$\mathbf{N}$} & Valid & 30 \\
\hline & Missing & $\mathrm{O}$ \\
\hline \multicolumn{2}{|c|}{ Mean } & 70,10 \\
\hline \multicolumn{2}{|c|}{ Median } & 70,00 \\
\hline \multicolumn{2}{|c|}{ Mode } & 70 \\
\hline \multicolumn{2}{|c|}{ Std. Deviation } & 6,456 \\
\hline \multicolumn{2}{|c|}{ Variance } & 41,679 \\
\hline \multicolumn{2}{|c|}{ Range } & 29 \\
\hline \multicolumn{2}{|c|}{ Minimum } & 56 \\
\hline \multicolumn{2}{|c|}{ Maximum } & 85 \\
\hline \multicolumn{2}{|l|}{ Sum } & 2103 \\
\hline
\end{tabular}

Berdasarkan gambar 4.3 di atas, dapat dilihat bahwa jumlah responden yang dijadikan sampel berjumlah 30 orang dengan skor total kuesioner motivasi kepala sekolah sebesar 2103 dari 20 item pernyataan yang dijabarkan pada kuesioner motivasi kepala sekolah. Mean atau nilai rata-rata 70,10 dengan standar deviasi sebesar 6,45 dan Skor jawaban tertinggi sebesar 85 dan terendah sebesar 56. Berdasarkan analisa jumlah data maximum dan minimum tersebut maka peneliti dapat membuat kategori atau klasifikasi skor pada motivasi kepala sekolah. Adapun tabel pengkategorian motivasi kepala sekolah akan dijabarkan pada tabel 4.15 di bawah ini.

Tabel 4.15 Kategori Motivasi Kepala Sekolah

\begin{tabular}{|l|l|l|}
\hline No & Skor & Kategori \\
\hline 1 & $74-82$ & Sangat Baik \\
\hline 2 & $68-74$ & Baik \\
\hline 3 & $62-68$ & Cukup \\
\hline 4 & $56-62$ & Kurang Baik \\
\hline
\end{tabular}


Berdasarkan tabel tentang kategori motivasi kepala sekolah di atas, dapat dilihat bahwa motivasi kepala sekolah pada Madrasah Aliyah Unggulan Himatul Amanah Bendunganjati Pacet Kabupaten Mojokerto berada pada rata-rata 70,10 dengan kategori baik karena berada pada interval $68-74$.

2. Kinerja Guru

Peneliti akan memaparkan dan membahas data hasil penelitian yang meliputi skor total yang dikhusukan pada variabel kinerja guru di Madrasah Unggulan Hikmatul Amanah Bendunganjati Pacet Kabupaten Mojokerto sebagaimana yang dijabarkan pada tabel dibawah ini.

Tabel 4.16 Skor total kinerja guru

\begin{tabular}{|l|l|l|l|}
\hline No & Variabel & Jumlah Item & Skor Total \\
\hline 1 & Kinerja Guru & 15 & 1826 \\
\hline
\end{tabular}

Hasil penelitian juga akan dipaparkan dengan menggunakan analisis deskripsi statistik menggunakan bantuan Aplikasi SPSS 25.0 for windows seperti yang digambarkan pada pada gambar 4.4 dibawah ini.

Gambar Deskripsi Statistik Kinerja Guru

\begin{tabular}{|c|c|c|}
\hline \multicolumn{3}{|c|}{ Statistics } \\
\hline \multicolumn{3}{|c|}{ Kinerja Guru } \\
\hline \multirow[t]{2}{*}{$\mathbf{N}$} & Valid & 30 \\
\hline & M issing & 0 \\
\hline \multicolumn{2}{|l|}{ Mean } & 60,87 \\
\hline \multicolumn{2}{|l|}{ Median } & 62,50 \\
\hline \multicolumn{2}{|l|}{ Mode } & 64 \\
\hline \multicolumn{2}{|c|}{ Std. Deviation } & 6,474 \\
\hline \multicolumn{2}{|c|}{ Variance } & 41,913 \\
\hline \multicolumn{2}{|l|}{ Range } & 20 \\
\hline \multicolumn{2}{|c|}{ Minimum } & 50 \\
\hline \multicolumn{2}{|c|}{ M aximum } & 70 \\
\hline \multicolumn{2}{|l|}{ Sum } & 1826 \\
\hline
\end{tabular}

Berdasarkan gambar deskripsi statistik kinerja guru di atas, dapat dilihat bahwa jumlah responden yang dijadikan sampel berjumlah 30 orang dengan skor total kuesioner kinerja guru sebesar 1826 dari 15 item pernyataan yang dijabarkan pada kuesioner kinerja guru. Mean atau nilai rata-rata 61 dengan standar deviasi sebesar 6,47 dan skor jawaban tertinggi sebesar 70 dan terendah sebesar 50 . Berdasarkan analisa jumlah data maximum dan minimum tersebut maka peneliti dapat membuat kategori atau klasifikasi skor pada kinerja guru. Adapun tabel pengkategorian kinerja guru akan dijabarkan pada tabel 4.17 di bawah ini. 
Tabel Kategori Kinerja Guru

\begin{tabular}{|l|l|l|}
\hline No & Skor & Kategori \\
\hline 1 & $68-74$ & Sangat Baik \\
\hline 2 & $62-68$ & Baik \\
\hline 3 & $56-62$ & Cukup \\
\hline 4 & $50-56$ & Kurang Baik \\
\hline
\end{tabular}

Berdasarkan tabel tentang kategori kinerja guru di atas, dapat dilihat bahwa kinerja guru pada Madrasah Aliyah Unggulan Himatul Amanah Bendunganjati Pacet Kabupaten Mojokerto berada pada rata-rata 61 dengan kategori cukup karena berada pada interval $56-62$.

\section{Pengujian Hipotesis}

Peneliti akan memaparkan tahapan uji prasyarat analisis yang meliputi uji normalitas, uji multikoleniaritas dan uji heteroskedasitas. Uji prasrata analisis ini akan membuktikan bahwa data hasil penelitian dapat digunakan dan dianalisis. Untuk Prasyarat analisis, Uji t dan Uji F akan diapaparkan sebagai berikut.

1. Uji Prasyarat Analisis

a. Uji Normalitas

Uji normalitas pada penelitian ini menggunakan distribusi pada grafik P-P plot. Berikut ini hasil uji normalitas menggunakan grafik P-P Plot menggunakan bantuan aplikasi SPSS versi 25.0 for windows.

Gambar Hasil pengujian data dengan Normal Probality Plot

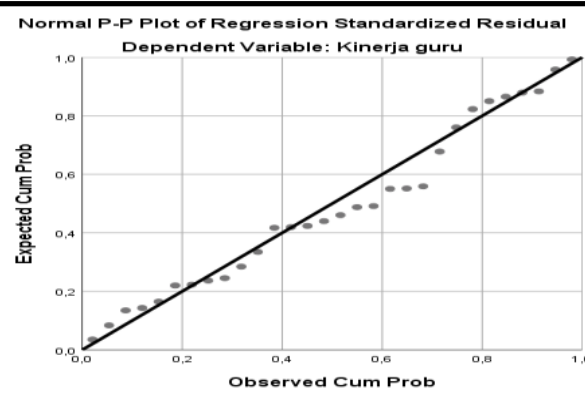

Gambar hasil pengujian data dengan Normal Probality Plot diatas menunjukan bahwa data menyebar disekita rgaris diagonal dan mengikuti arah garis diagonal pada grafik histogram, hal ini menerangkan bahwa pola distribusi normal. Sehingga dapat disimpulkan bahwa berdasarkan grafik P-P plot, model regresi memenuhi asumsi normalitas. Pengujian selanjutnya menggunakan Uji Kolmogrov-Smirnov diperoleh data seperti pada tabel di bawah ini.

Tabel Hasil uji normalitas data dengan uji kolmogrov-smirnov

\begin{tabular}{|l|l|}
\hline Variabel & Asymp.sig / P-Value \\
\hline Gaya kepemimpinan & 0,200 \\
\hline Motivasi kepala sekolah & 0,122 \\
\hline Kinerja guru & 0,073 \\
\hline
\end{tabular}


Berdasarkan tabel Hasil uji normalitas data dengan uji kolmogrov-smirnov diatas, nilai-P data gaya kepemimpinan adalah 0,200. Berdasarkan kriteria pengujian, $P$-Value $\geq \alpha(0,200 \geq 0,05)$ maka data gaya kepemimpinan dikatakan berasal dari populasi berdistribusi normal. Nilai-P untuk data motivasi kepala sekolah yaitu 0,122 . Berdasarkan kriteria pengujian, $P$-Value $\geq \alpha(0,122 \geq 0,05)$ maka data motivasi kepala sekolah dikatakan berasal dari populasi berdistribusi normal. Adapun nilai-P data kinerja guru yaitu 0,073. Berdasarkan kriteria pengujian, $P$-Value $\geq \alpha(0,073 \geq 0,05)$ maka data kinerja guru dikatakan berasal dari populasi berdistribusi normal.

b) Uji Multikolinearitas

Cara mengetahui ada tidaknya penyimpangan uji multikolinieritas adalah dengan melihat nilai Tolerance dan VIF masing-masing variabel independen, jika nilai Tolerance $>0.10$ dan nilai VIF < 10, maka data bebas dari gejala multikolinieritas. Perhatikan tabel di bawah ini!

Tabel Tabel Uji Multikolinearitas

\begin{tabular}{|l|l|l|}
\hline Variabel & Tolerance & $\begin{array}{l}\text { Variance Inflation Factor } \\
(\text { VIF })\end{array}$ \\
\hline Gaya kepemimpinan & 0,995 & 1,005 \\
\hline Motivasi kepala sekolah & 0,995 & 1,005 \\
\hline
\end{tabular}

Pada tabel 4.19 diatas menunjukan hasil perhitungan nilai Tolerance tidak ada variabel independen yang memiliki nilai Tolerance kurang dari 0.10 dengan nilai Tolerance masing-masing variabel independen bernilai gaya kepemimpinan sebesar 0,995 dan motivasi kepala sekolah sebesar 0,995. Sementara itu hasil perhitungan nilai Variance Inflation Factor (VIF) juga menunjukkan hal serupa yaitu tidak adanya nilai Variance Inflation Factor (VIF) dari variabel independen yang memiliki nilai VIF lebih dari 10 dengan nilai Variance Inflation Factor (VIF) masing-masing variabel independen bernilai gaya kepemimpinan sebesar 1,005 dan motivasi kepala sekolah sebesar 1,005. Merujuk hasil perhitungan nilai Tolerance dan Variance Inflation Factor (VIF) diatas, dapat disimpulkan bahwa tidak terdapat multikolinieritas antar variabel independen dalam model regresi.

c) Uji Heteroskedasitas

Cara untuk mengetahui terjadi heteroskedastisitas atau tidak yaitu dengan melihat Grafik Plot antara nilai prediksi variabel dependen yaitu kinerja guru dengan residualnya Tidak terjadi heteroskedastisitas yaitu apabila tidak ada pola yang jelas, serta titik-titik menyebar di atas dan di bawaha ngka 0 pada sumbu Y. 


\section{Gambar Uji Heteroskedasitas}

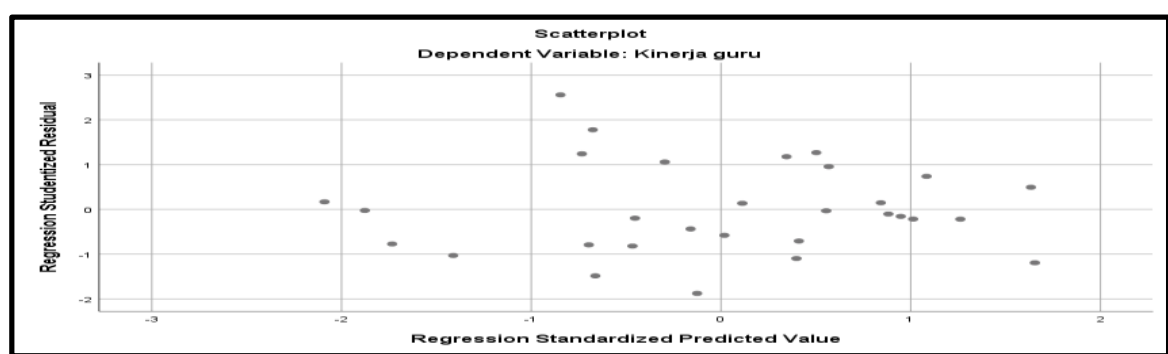

Berdasarkan gambar Uji Heteroskedasitas diatas terlihat bahwa tidak ada pola yang jelas serta titik-titik tersebut menyebar di atas dan di bawah angka 0 pada sumbu Y. Hal ini menunjukkan bahwa data dalam penelitian ini tidak terjadi heteroskedastisitas.

1. Uji Hipotesis (Uji t)

1) Pengaruh gaya kepemimpinan terhadap kinerja guru.

a) Persamaan regresi variabel X1 (Gaya kepemimpinan) terhadap Y (Kinerja guru)

$$
\text { Gambar Persamaan regresi variabel X1 (Gaya kepemimpinan) }
$$
terhadap Y (Kinerja guru)

\begin{tabular}{|c|c|c|c|c|c|c|c|c|}
\hline \multicolumn{9}{|c|}{ Coefficients $^{\mathrm{a}}$} \\
\hline \multirow{2}{*}{\multicolumn{2}{|c|}{ Model }} & \multicolumn{2}{|c|}{$\begin{array}{c}\text { Unstandardized } \\
\text { Coefficients } \\
\end{array}$} & \multirow{2}{*}{ 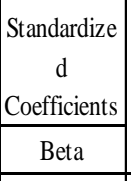 } & \multirow[b]{2}{*}{ t } & \multirow[b]{2}{*}{ Sig. } & \multicolumn{2}{|c|}{ Collinearity Statistics } \\
\hline & & B & Std. Error & & & & Tolerance & VIF \\
\hline \multirow[t]{2}{*}{1} & (Constant) & 33,225 & 10,109 & & 3,287 & 0,003 & & \\
\hline & \begin{tabular}{|c|} 
Gaya \\
kepemimpinan
\end{tabular} & 0,347 & 0,126 & 0,461 & 2,750 & 0,010 & 1,000 & 1,000 \\
\hline & & & a. Dep & Variable: & guru & & & \\
\hline
\end{tabular}

$$
\overline{\mathrm{Y}}=33,225+0,347 \mathrm{X} 1
$$

Data pada gambar Persamaan regresi variabel X1 (Gaya kepemimpinan) terhadap Y (Kinerja guru) diatas menunjukan bahwa variabel gaya kepemimpina memiliki hubungan dengan variabel kinerja guru, yaitu jika variabel gaya kepemimpinan mengalami peningkatan satu satuan, maka variabel kinerja guru juga akan mengalami peningkatan satu satuan. 
b) Menghitung besar korelasi antara $X_{1}$ dan $Y$

Nilai $r=0,461$, menunjukan bahwa gaya kepemipinan dan kinerja guru memiliki hubungan linear positif yaitu terjadi hubungan searah antara X1 terhadap $\mathrm{Y}$ yang berarti jika gaya kepemimpinan semakin tinggi maka kinerja guru pun meningkat.

c) Uji hipotesis X1 terhadap Y

Berdasarkan uji hipotesis yang telah dilakukan diperoleh nilai $t_{\text {hitung }}=$ 2,750. Dengan membandingkan $t_{\text {hitung }}$ dengan $t_{\text {table }}$ pada taraf $\alpha=5 \%$ maka diperoleh nilai $t_{\text {hitung }}>t_{\text {table }}(2,750>2,048)$ yang berarti bahwa $\mathrm{H}_{0}$ ditolak dan $\mathrm{H}_{\mathrm{a}}$ diterima. Hal ini menunjukkan bahwa terdapat pengaruh positif gaya kepemimpinan terhadap kinerja guru di Madarsah Aliyah Unggulan Hikmatul Amanah Bendunganjati Pacet Kabupaten Mojokerto. Pengujian hipotesis menggunakan bantuan aplikasi SPSS 25.0 for windows sebagai berikut:

Tabel Hasil uji hipotesis X1 terhadap Y

\begin{tabular}{|l|l|}
\hline Gaya kepemimpinan terhadap kinerja guru \\
\hline$P$-Value & 0,010 \\
\hline
\end{tabular}

Berdasarkan tabel 4.20 diatas, diperoleh nilai-P sebesar 0,010. Kriteria pengujian hipotesis, P-Value $>\alpha(0,010>0,05)$ sehingga Hal diterima dan H01 ditolak, dengan demikian, terdapat pengaruh gaya kepemimpinan terhadap kinerja guru di Madrasah Aliyah Unggulan Hikmatul Amanah Bendunganjati. Berdasarkan hasiil uji hipotesis pertama diketahui bahwa gaya kepemimpinan berpengaruh positif dan signifikan terhadap kinerja guru yang ditunjukan dengan hasil uji $t$ diperoleh harga $t_{\text {hitung }}$ sebesar 2,750 lebih besar dibandingkan $t_{\text {tabel }}$ sebesar 2,048 dengan taraf signifikansi 5\% dengan koefisien determinan sebesar 0,461 sehingga dapat disimpulkan bahwa kinerja guru dipengaruhi oleh gaya kepemimpinan sebesar $46,1 \%$. 
2) Pengaruh motivasi kepala sekolah terhadap kinerja guru.

a) Persamaan regresi X2 (Motivasi kepala sekolah) terhadap Y (Kinerja guru)

Gambar Persamaan regresi X2 (Motivasi kepala sekolah) terhadap Y (Kinerja guru)

\begin{tabular}{|c|c|c|c|c|c|c|c|c|}
\hline \multicolumn{9}{|c|}{ Coefficients $^{\mathrm{a}}$} \\
\hline & & \multicolumn{2}{|c|}{$\begin{array}{l}\text { Unstandardized } \\
\text { Coefficients }\end{array}$} & \multirow{2}{*}{$\begin{array}{c}\begin{array}{c}\text { Standardize } \\
\mathrm{d} \\
\text { Coefficients }\end{array} \\
\text { Beta } \\
\end{array}$} & \multirow[b]{2}{*}{$\mathrm{t}$} & \multirow[b]{2}{*}{ Sig. } & \multicolumn{2}{|c|}{ Collinearity Statistics } \\
\hline \multicolumn{2}{|c|}{ Model } & B & Std. Error & & & & Tolerance & VIF \\
\hline \multirow[t]{2}{*}{1} & (Constant) & 27,728 & 11,764 & & 2,357 & 0,026 & & \\
\hline & $\begin{array}{c}\text { Motivasi } \\
\text { kepala } \\
\text { sekolah } \\
\end{array}$ & 0,473 & 0,167 & 0,471 & 2,829 & 0,009 & 1,000 & 1,000 \\
\hline \multicolumn{9}{|c|}{ a. Dependent Variable: Kinerja guru } \\
\hline
\end{tabular}

$$
\overline{\mathrm{Y}}=27,728+0,437 \mathrm{X} 2
$$

Data pada gambar diatas menunjukan bahwa variabel motivasi kepala sekolah memiliki hubungan dengan variabel kinerja guru, yaitu jika variabel motivasi kepala sekolah mengalami peningkatan satu satuan, maka variabel kinerja guru juga akan mengalami peningkatan satu satuan.

b) Menghitung besar korelasi antara X2 dan Y

Nilai $r=0,471$, menunjukan bahwa motivasi kepala sekolah dan kinerja guru memiliki hubungan linear positif yaitu terjadi hubungan searah antara X2 terhadap Y yang berarti jika motivasi kepala sekolah semakin tinggi maka kinerja guru pun meningkat.

c) Uji hipotesis X2 terhadap Y

Berdasarkan uji hipotesis yang telah dilakukan diperoleh nilai $t_{\text {hitung }}=$ 2,829. Dengan membandingkan $t_{\text {hitung }}$ dengan $t_{\text {table }}$ pada taraf $\alpha=5 \%$ maka diperoleh nilai $t_{\text {hitung }}<t_{\text {table }}(2,829>2,048)$ yang berarti bahwa $\mathrm{H}_{0}$ ditolak dan $\mathrm{H}_{\mathrm{a}}$ diterima. Hal ini menunjukkan bahwa terdapat pengaruh positif antara motivasi kepala sekolah terhadap kinerja guru di Madarsah Aliyah Unggulan Hikmatul Amanah Bendunganjati Pacet Kabupaten Mojokerto. Pengujian hipotesis dibantu dengan menggunakan aplikasi SPSS 25.0 for windows sebagai berikut:

Tabel Hasil uji hipotesis X2 Terhadap Y

Motivasi kepala sekolah terhadap kinerja guru

\begin{tabular}{l|l}
$P$-Value & 0,009
\end{tabular}

Berdasarkan tabel Hasil uji hipotesis X2 Terhadap Y diatas, diperoleh nilai-P sebesar 0,009. Kriteria pengujian hipotesis, P-Value $<\alpha(0,009<0,05)$ sehingga Ha1 diterima dan H01 ditolak, dengan demikian, terdapat pengaruh 
motivasi kepala sekolah terhadap kinerja guru di Madrasah Aliyah Unggulan Hikmatul Amanah Bendunganjati Pacet Kabupaten Mojokerto.

Berdasarkan hasil uji hipotesis ke dua diketahui bahwa motivasi kepala sekolah berpengaruh positif terhadap kinerja guru yang ditunjukan dengan hasil uji $t$ diperoleh $t_{\text {hitung }}$ sebesar 2,829 lebih besar dari pada $t_{\text {tabel }}$ sebesar 2,048 pada tarah signifikan 5\% dengan koefisien determinan 0,471 sehingga dapat disimpulkan bahwa kinerja guru dipengaruhi oleh motivasi kepala sekolah sebesar $47,1 \%$.

3) Pengaruh gaya kepemimpinan dan motivasi kepala sekolah secara simultan terhadap kinerja guru.

a) Uji regresi linear berganda

Analisis regresi linier berganda adalah hubungan secara linear antara dua atau lebih variabel independen dalam penelitian ini adalah gaya kepemimpinan (X1) dan motivasi kepala sekolah (X2) dengan variabel dependen dalam penelitian ini adalah kinerja guru (Y). Analisis ini untuk mengetahui arah hubungan antara variabel independen dengan variabel dependen apakah masingmasing variabel independen berhubungan positif atau negatif dan untuk memprediksi nilai dari variabel dependen apabila nilai variabel independen mengalami kenaikan atau penurunan dengan persamaan regresi ganda sebagai berikut : $Y=a+b_{1} X_{1}+b_{2} X_{2} \quad$ yang akan diuji dengan menggunakan bantuan aplikasi SPPS versi 25.0 for windows.

Gambar 4.9 Uji regresi linear berganda

\begin{tabular}{|c|c|c|c|c|c|c|}
\hline \multicolumn{7}{|c|}{ Coefficients $^{a}$} \\
\hline \multirow{2}{*}{\multicolumn{2}{|c|}{ Model }} & \multicolumn{2}{|c|}{$\begin{array}{l}\text { Unstandardized } \\
\text { Coefficients }\end{array}$} & \multirow{2}{*}{$\begin{array}{c}\text { Standardized } \\
\text { Coefficients } \\
\text { Beta } \\
\end{array}$} & \multirow[b]{2}{*}{$\mathrm{t}$} & \multirow[b]{2}{*}{ Sig. } \\
\hline & & B & Std. Error & & & \\
\hline \multirow[t]{3}{*}{1} & (Constant) & 3,936 & 13,286 & & 0,296 & 0,769 \\
\hline & \begin{tabular}{|c|} 
Gaya \\
kepemimpinan
\end{tabular} & 0,325 & 0,112 & 0,431 & 2,903 & 0,007 \\
\hline & \begin{tabular}{|c|} 
Motivasi \\
kepala sekolah
\end{tabular} & 0,443 & 0,149 & 0,442 & 2,978 & 0,006 \\
\hline \multicolumn{7}{|c|}{ a. Dependent Variable: Kinerja guru } \\
\hline
\end{tabular}

$$
Y=39,36+0,325 X_{1}+0,443 X_{2}
$$


b) Nilai korelasi secara simultan

Gambar Nilai korelasi secara simultan antara (XI dan X2) terhadap Y

\begin{tabular}{|c|c|c|c|c|}
\hline \multicolumn{7}{|c|}{ Model Summary } \\
\hline Model & $\mathrm{R}$ & R Square & $\begin{array}{c}\text { Adjusted R } \\
\text { Square }\end{array}$ & $\begin{array}{c}\text { Std. Error } \\
\text { of the } \\
\text { Estimate }\end{array}$ \\
\hline 1 &, $638^{\mathrm{a}}$ & 0,407 & 0,363 & 5,166 \\
\hline \multicolumn{3}{|c|}{ a. Predictors: (Constant), Motivasi kepala sekolah, Gay a } \\
\hline
\end{tabular}

Berdasarkan gambar nilai korelasi secara simultan antara (XI dan X2) terhadap Y diatas, diperoleh nilai koefisien korelasi $r=0,638$. Nilai sebesar 0,638 menunjukan bahwa hubungan secara simultan antara gaya kepemimpinan dan motivasi kepala sekolah terhadap kinerja guru memiliki hubungan yang kuat. Sedangkan koefisien determinan sebesar 40,7\%, sehingga bisa di kategorikan gaya kepemimpinan dan motivasi kepala sekolah menyumbang 40,7 \% pengaruhnya terhadap kinerja guru sedangkan 59,3\% dipengaruhi oleh faktor lain.

c) Uji hipotesis secara simultan.

Gambar Uji Hipotesis Secara Simultan

\begin{tabular}{|c|c|c|c|c|c|c|}
\hline \multicolumn{7}{|c|}{$\mathbf{A N O V A}^{\mathbf{a}}$} \\
\hline \multicolumn{2}{|c|}{ Model } & $\begin{array}{l}\text { Sum of } \\
\text { Squares }\end{array}$ & df & $\begin{array}{l}\text { Mean } \\
\text { Square }\end{array}$ & $\mathrm{F}$ & Sig. \\
\hline \multirow[t]{3}{*}{1} & Regression & 495,024 & 2 & 247,512 & 9,276 &, $001^{\mathrm{b}}$ \\
\hline & Residual & 720,443 & 27 & 26,683 & & \\
\hline & Total & 1215,467 & 29 & & & \\
\hline \multicolumn{7}{|c|}{ a. Dependent Variable: Kinerja guru } \\
\hline
\end{tabular}

Berdasarkan uji hipotesis yang telah dilakukan diperoleh nilai $f_{\text {hitung }}=9,276$. Dengan membandingkan $f_{\text {hitung }}$ dengan $f_{\text {table }}$ pada taraf $\alpha=5 \%$ maka diperoleh nilai $f_{\text {hitung }}>f_{\text {table }}(9,276>3,34)$ yang berarti bahwa $\mathrm{H}_{0}$ ditolak dan $\mathrm{H}_{\mathrm{a}}$ diterima.

\section{PEMBAHASAN}

1. Gaya Kepemimpinan Kepala Sekolah terhadap Kinerja Guru

Pemimpin yang dimkasudkan dalam penelitian ini adalah kepala sekolah/Kepala madarsah. Hasil penelitian yang diperoleh menunjukan bahwa gaya kepemimpinan mempunyai pengaruh positif dan signifikan terhadap kinerja guru. Gaya kepemimpinan kepala sekolah sangat berpengaruh kuat pada semua guru sehingga guru terpacu melakukan kegiatan belajar mengajar dan mendapatkan dukungan moril dalam meningkatan kemampuan dan kinerjanya 
sebagai seorang guru profesional dalam rangka perbaikan mutu pembelajaran di sekolah tersebut.

Dalam penelitian ini, gaya kepemimpina kepala sekolah hanya menyumbang 46,1\% dari $100 \%$ faktor yang dapat mempengaruhi kinerja guru antara lain: gaji/kompensasi, faktor personal/individu yang meliputi unsur pengetahuan atau akademik, keterampilan (skill), kemampuan, kepercayaan diri, motivasi dan komitmen kuat yang dimiliki oleh tiap individu guru, sarana dan prasarana, lingkungan kerja yang kondusif, faktor kepemimpinan yang meliputi aspek kualitas kepala sekolah sebagai leader atau manajer dalam memberikan dorongan, semangat, arahan, dan dukungan kerja pada para guru, faktor team work yang meliputi saling memotivasi sesama anggota dalam satu tim kerja, saling percaya anatara satu anggota dangan anggota lainnya, kekompakan dan kerjasama yang baik, faktor kontekstual (situasional) yang meliputi tekanan dan perubahan lingkungan eksternal individu dan kelompok terhadap kinerja guru dan lebih umumnya adalah mutu lembaga pendidikan tersebut.

2. Motivasi Kepala Sekolah terhadap Kinerja Guru

Hasil penelitian yang diperoleh oleh peneliti menunjukan bahwa motivasi kepala sekolah berpengaruh positif terhadap kinerja guru. Motivasi kepala sekolah sangat dibutuhkan oleh guru agar guru lebih bersemangat dalam melaksanakan tugasnya sebagai pengajar, pendidik dan pembina pada sekolah/madrasah.

Dari hasil analisis diatas, motivasi kepala sekolah mampu mempengaruhi kinerja guru sebesar 47,1\% dari 100\% faktor yang mempengaruhi kinerja guru. Motivasi kepala sekolah sangat memiliki peran sentral dalam mempengaruhi kinerja guru. Kepala sekolah yang kurang bahkan tidak memberikan motivasi pada bawahan/guru akan cendrung membuat guru tidak bersemangat dan merasa tidak diperhatikan sehingga guru pun bertindak semaunya dan bekerja tanpa merasa ada yang menghargai dan memperhatikan profesinya sebagai pengajar, pendidik dan pembina di sekolah. Hal demikian akan menimbulkan sikap acuh dan apatis dalam pribadi guru dan cendrung bekerja tidak efektif sehingga dapat menurunkan kinerja guru dan mutu sekolah/madrasah. Adapun 52,9\% lainnya dipengaruhi oleh banyak faktor antara lain faktor kepemimpinan kepala sekolah, gaji/dispensasi, lingkungan madrsah yang kondusif, faktor personal/pribadi yang meliputi unsur pengetahuan, keterampilan (skill), kemampuan akademik maupun non akademik, kepercayaan diri, dan komitmen menjadi guru profesional yang dimiliki oleh individu guru, faktor kepemimpinan meliputi aspek kualitas manajer dan term leader dalam memberikan teladan, arahan, semngat, dan dukungan kerja kepada guru baik berupa dukungan moral, saran dan prasarana serta fasilitas penunang pembelajaran lainnya, faktor team work meliputi kualitas dukungan dan kekuatan serta motivasi sesama rekan guru dalam suatu tim kerja, kekompakan, 
keeratan anggota tim, faktor kontekstual (situasional), meliputi tekanan dan perubahan lingkungan eksternal individu dan kelompok terhadap kinerja guru khususnya dan mutu lembaga pada umumnya.

3. Pengaruh Gaya Kepemimpinan dan Motivasi Kepala Sekolah secara Simultan terhadap Kinerja Guru.

Hasil penelitian menunjukan terdapat pengaruh positif secara simultan antara gaya kepemimpinan dan motivasi kepala sekolah terhadap kinerja guru di Madarsah Aliyah Unggulan Hikmatul Amanah Bendunganjati, kemudian diperoleh nilai-P sebesar 0,001. Kriteria pengujian hipotesis, P-Value $<\alpha(0,001$ $<0,05)$ sehingga Ha diterima dan H0 ditolak, dengan demikian, terdapat pengaruh secara simultan antara gaya kepemimpinan dan motivasi kepala sekolah terhadap kinerja guru di Madrasah Aliyah Unggulan Hikmatul Amanah Bendunganjati Pacet Kabupaten Mojokerto.

Berdasarkan hasil uji hipotesis tiga tentang pengaruh simultan anatara gaya kepemimpinan dan motivasi kepala sekolah terhadap kinerja guru, diketahui bahwa gaya kepemimpinan dan motivasi kepala sekolah terhadap kinerja guru berpengaruh positif dan signifikan terhadap kinerja guru yang ditunjukan dengan hasil uji f diperoleh harga f_hitung sebesar 9,276 lebih besar dari pada f_tabel 3,34 pada taraf signifikan 5\% dengan koefisien korelasi sebesar 0,638, menunjukan bahwa hubungan secara simultan antara gaya kepemimpinan dan motivasi kepala sekolah terhadap kinerja guru memiliki hubungan yang kuat. Sedangkan koefisien determinan sebesar 40,7\%, sehingga bisa di kategorikan gaya kepemimpinan dan motivasi kepala sekolah menyumbang 40,7 \% pengaruhnya terhadap kinerja guru, sedangkan 59,3\% dipengaruhi oleh faktor lain, yang meliputi: faktor kepemimpinan kepala sekolah, gaji/dispensasi, lingkungan madrsah yang kondusif, faktor personal/pribadi yang meliputi unsur pengetahuan, keterampilan (skill), kemampuan akademik maupun non akademik, kepercayaan diri, dan komitmen menjadi guru profesional yang dimiliki oleh individu guru, faktor kepemimpinan meliputi aspek kualitas manajer dan term leader dalam memberikan teladan, arahan, semngat, dan dukungan kerja kepada guru baik berupa dukungan moral, saran dan prasarana serta fasilitas penunjang pembelajaran lainnya, faktor team work meliputi kualitas dukungan dan kekuatan serta motivasi sesama rekan guru dalam suatu tim kerja, kekompakan, keeratan anggota tim, faktor kontekstual (situasional), meliputi tekanan dan perubahan lingkungan eksternal individu dan kelompok terhadap kinerja guru khususnya dan mutu lembaga pada umumnya. 


\section{KESIMPULAN}

Berdasarkan hasil analisis dan pembahasan data yang dilanjutkan dengan pembuktian hipotesis, dapat disimpulkan bahwa :

1. Terdapat pengaruh positif dan signifikan antara gaya kepemimpinan terhadap kinerja guru. Hal tersebut didasarkan pada analisis hipotesis menggunakan aplikasi SPSS Versi 25.0 For windows yang menunjukan bahwa hasil uji t diperoleh dari $t_{\text {hitung }}$ sebesar 2,750 sedangkan nilai $t_{\text {tabel }}$ sebesar 2,048 pada taraf signifikan $5 \%$ maka 2,750>2,048 atau $t_{\text {hitung }}>t_{\text {tabel }}$, sehingga dapat disimpulkan bahwa $\mathrm{H}_{0}$ ditolak dan $\mathrm{H}_{\mathrm{a}}$ diterima dengan koefisien determinan sebesar 0,347 atau 34,7\% . Berdasarkan hasiil uji hipotesis pertama diketahui bahwa gaya kepemimpinan berpengaruh positif dan signifikan terhadap kinerja guru yang ditunjukan dengan hasil uji $t$ diperoleh harga $t_{\text {hitung }}$ sebesar 2,750 lebih besar dibandingkan $t_{\text {tabel }}$ sebesar 2,048 dengan taraf signifikansi $5 \%$ dan koefisien determinan sebesar 0,461 sehingga dapat disimpulkan bahwa kinerja guru dipengaruhi oleh gaya kepemimpinan sebesar 46,1\%. Hal ini menunjukkan bahwa terdapat pengaruh positif dan sgnifikan antara gaya kepemimpinan terhadap kinerja guru di Madarsah Aliyah Unggulan Hikmatul Amanah Bendunganjati Pacet Kabupaten Mojokerto. Gaya kepemimpina kepala sekolah hanya menyumbang $46,1 \%$ dari $100 \%$ faktor yang dapat mempengaruhi kinerja guru antara lain, sedangkan 53,9\% dipengaruhi oleh faktor-faktor lain.

2. Terdapat pengaruh positif dan signifikan antara motivasi kepala sekolah terhadap kinerja guru di Madarsah Aliyah Unggulan Hikmatul Amanah Bendunganjati Pacet Kabupaten Mojokerto. Hasil uji hipotesis ke dua diketahui bahwa motivasi kepala sekolah berpengaruh positif terhadap kinerja guru yang ditunjukan dengan hasil uji $\mathrm{t}$ diperoleh $\mathrm{t}_{\text {hitung }}$ sebesar 2,829 lebih besar dari pada $t_{\text {tabel }}$ sebesar 2,048 pada tarah signifikan 5\% yang berarti bahwa $\mathrm{H}_{0}$ ditolak dan $\mathrm{H}_{\mathrm{a}}$ diterima dengan koefisien determinan 0,471 sehingga dapat disimpulkan bahwa kinerja guru dipengaruhi oleh motivasi kepala sekolah sebesar 47,1\%. Dari hasil analisis, motivasi kepala sekolah mampu mempengaruhi kinerja guru sebesar $47,1 \%$ dari $100 \%$ faktor yang mempengaruhi kinerja guru sedangkan 52,9\% dipengaruhi oleh faktor lain.

3. Terdapat pengaruh positif dan signifikan secara simultan antara gaya kepemimpinan dan motivasi kepala sekolah terhadap kinerja guru di Madarsah Aliyah Unggulan Hikmatul Amanah Bendunganjati Pacet Kabupaten Mojokerto yang dibuktikan melalui uji hipotesis dengan nilai $f_{\text {hitung }}$ $=9,276$. Dengan membandingkan $f_{\text {hitung }}$ dengan $f_{\text {table }}$ pada taraf $\alpha=5 \%$ maka diperoleh nilai $f_{\text {hitung }}>f_{\text {table }}(9,276>3,34)$ yang berarti bahwa $\mathrm{H}_{0}$ ditolak dan $\mathrm{H}_{\mathrm{a}}$ diterima. kemudian diperoleh nilai-P sebesar 0,001 . Kriteria pengujian 
hipotesis, $\mathrm{P}-$ Value $<\alpha(0,001<0,05)$ sehingga $\mathrm{Ha}$ diterima dan $\mathrm{H}_{0}$ ditolak, dengan demikian, terdapat pengaruh secara simultan antara gaya kepemimpinan dan motivasi kepala sekolah terhadap kinerja guru di Madrasah Aliyah Unggulan Hikmatul Amanah Bendunganjati Pacet Kabupaten Mojokerto. Berdasarkan hasil uji hipotesis tiga tentang pengaruh simultan anatara gaya kepemimpinan dan motivasi kepala sekolah terhadap kinerja guru, diketahui bahwa gaya kepemimpinan dan motivasi kepala sekolah terhadap kinerja guru berpengaruh positif dan signifikan terhadap kinerja guru yang ditunjukan dengan hasil uji f diperoleh harga $\mathrm{f}_{\text {hitung }}$ sebesar 9,276 lebih besar dari pada $\mathrm{f}_{\text {tabel }}$ 3,35 pada taraf signifikan 5\% dengan koefisien korelasi sebesar 0,638, menunjukan bahwa hubungan secara simultan antara gaya kepemimpinan dan motivasi kepala sekolah terhadap kinerja guru memiliki hubungan yang kuat. Sedangkan koefisien determinan sebesar 40,7\%, sehingga bisa di kategorikan gaya kepemimpinan dan motivasi kepala sekolah menyumbang 40,7 \% pengaruhnya terhadap kinerja guru, sedangkan 59,3\% dipengaruhi oleh faktor lain.

\section{DAFTAR PUSTAKA}

Aan Ansori, Ahmad Supriyanto, Burhanuddin Burhanuddin, "PELAKSANAAN SUPERVISI KLINIS DALAM MENINGKATKAN KINERJA GURU SEKOLAH DASAR," Jurnal Pendidikan: Teori, Penelitian, dan Pengembangan 1, no. 12 (December 1, 2016): 2323, https://doi.org/10.17977/jp.v1i12.8285.

Ardial, Paradigma dan Model Penelitian Komunikasi, Jakarta: Bumi Aksara, 2014

Arifin. Zainal. Evaluasi pembelajaran. Bandung: PT. Remaja Rosda Karya, 2016 Aunurrahman. Belajar dan Pembelajaran. Bandung: Alfabeta, 2013

Ananto Pramadhika, "Motivasi Kerja Dalam Islam" Jurnal Motivasi Kerja, September 2011

Baharudin, Umairso. Kepemimpinan Pendidikan Islam . (Jogjakarta, , Ar Ruzz Media,) 2012

Daryanto. Standar Kompetensi dan Penilaian Kinerja Guru Profesional. Yogyakarta: Penerbit Gava Media, 2013

e-Journal Program Pascasarjana Universitas Pendidikan Ganesha. Ari Wahyu Ningrat Karang, Dkk. Studi Hubungan Antara Kepemimpinan Kepala Sekolah, Kompetensi Profesional, Dan Motivasi Kerja Guru Terhadap Kinerja Guru SMP Negeri 1 Bangli (Singaraja,Volume 4 Tahun 2013) E. Mulyasa. Manajemen Berbasis Sekolah. (Bandung:PT. Remaja
Rosdakarya,2014). 
Hasan Basri. Kepemimpinan Kepala Sekolah. Bandung: CV. Pustaka Setia, 2014.

Hasibuan. Manajemen Sumber Daya Manusia . Jakarta; PT Bumi Aksara 2016.

Hamzah B. U. Teori Motivasi\& Pengukurannya. Jakarta: PTBumi Aksara. 2013.

Hikmat. Manajemen Pendidikan.. Bandung: CV. Pustaka Setia, 2014.

Khan, A., Shah, I. M., Khan, S., et al. (2012). Teacher Stress, Performance \& Resour-ces The Moderating Effect of Resour-ces on Stress and Performnace. Inter-national Review of Social Science and Humanities, Vol.2, No. 2, 21-29

Priansa dan Somad.Manajemen supervisi dan kepemimpinan kepala sekolah. Bandung: Alfabeta, 2014

Sahertian, P.A \& Saherian, I. A. 1995. Supervisi Pendidikan Dalam Rangka Program Inservise Education. Jakarta: Rineka Cipta.

Sahertian, P.A. 2008. Konsep Dasar \& Teknik Supervisi Pendidikan: Dalam Pengembangan Sumber Daya Manusia. Jakarta: Rineka Cipta

Sardiman. Interaksi \& MotivasiBelajar Mengajar. Jakarta: Rajagarfindo Persada, 2012

Sugiyono, Metode Penelitian Kuantitatif, Kualitatif Dan R\&D, Bandung: Alfabeta, 2016

Suriyanto \& Maharani. Metodolgi Penelitian Manajemen Sumber Daya Manusia. Malang: UIN - Maliki Press, 2013

Usman, H dan Setiady, P. Metodologi Penelitian Sosial. Jakarta: PT Bumi Aksara. 2006

Wahyu Ramadoni, Kusmintardjo Kusmintardjo, and Imron Arifin, "KEPEMIMPINAN KEPALA SEKOLAH DALAM UPAYA PENINGKATAN KINERJA GURU (STUDI MULTI KASUS DI PAUD ISLAM SABILILLAH DAN SDN TANJUNGSARI 1 KABUPATEN SIDOARJO)," Jurnal Pendidikan: Teori, Penelitian, dan Pengembangan 1, no. 8 (August 1, 2016): 1502, https://doi.org/10.17977/jp.v1i8.6620. 